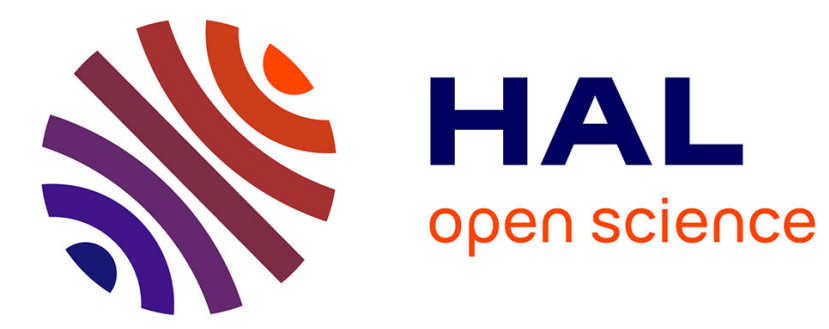

\title{
Cultural Policy Regimes in Western Europe Vincent Dubois
}

\section{To cite this version:}

Vincent Dubois. Cultural Policy Regimes in Western Europe. 2013. halshs-00836422

\section{HAL Id: halshs-00836422 \\ https://shs.hal.science/halshs-00836422}

Preprint submitted on 21 Jun 2013

HAL is a multi-disciplinary open access archive for the deposit and dissemination of scientific research documents, whether they are published or not. The documents may come from teaching and research institutions in France or abroad, or from public or private research centers.
L'archive ouverte pluridisciplinaire HAL, est destinée au dépôt et à la diffusion de documents scientifiques de niveau recherche, publiés ou non, émanant des établissements d'enseignement et de recherche français ou étrangers, des laboratoires publics ou privés. 


\title{
Cultural Policy Regimes in Western Europe
}

International Encyclopedia of the Social \& Behavioral Sciences, $2^{\text {nd }}$ edition, Elsevier, forthcoming, 2014.

\section{Vincent Dubois}

Université de Strasbourg, SAGE UMR 7363

MISHA, 5 allée du Général Rouvillois CS 50008 - F-67083 Strasbourg cedex FRANCE

+33(0)368856170 vincent.dubois@misha.fr

\begin{abstract}
European countries have built cultural policy regimes, which reflect the patterns of national political histories and of national cultural fields. These models consist in various ways of establishing culture as a policy domain, in the definition of cultural policy rationales, and in modes of organization and of governance compatible with democratic standards. This triple specification process has never been fully achieved. It is being challenged in a way that questions these policy regimes and the notion of cultural policy they had defined.
\end{abstract}

Keywords: Cultural policy; Europe; Art; Government; State; Patronage; Institutions; Public administration; Cultural participation; Heritage 


\section{Introduction}

Cultural policy regimes reflect the histories of nation and state building, the institutional configurations and the modes of government specific to each country. The cultural policy programs that most western European governments have elaborated during the second half of the $20^{\text {th }}$ century were based on the legacy of the plurisecular history of the relationships between the state and the arts, and between politics and culture. They were also linked with the general renewal of state intervention that consisted in the making of democratic welfare states after World War II. In that sense, contemporary cultural policies cannot be reduced to state patronage of the arts. They have defined their specific rationales, practices and modes of organization, according to the national political and institutional patterns, and following their changes through time. Cultural policy regimes also reflect the patterns of the national cultural fields, that is to say their socio-economic structure, their internal hierarchies and the conceptions of art and culture that prevail within them. The respective importance of heritage and of the cultural industries, the polycentric or centralized organization of the arts, the social distribution of tastes and cultural participation are part of the evolutive factors that shape specific national cultural policies which, in turn, impact them.

The evolutions of cultural policies result from the interaction between these two levels, the political and the cultural one. They mostly consist in adding new layers of institutions, orientations and discourses rather than in radical changes, in a way that contemporary cultural policies can be viewed as the sedimentation of previous ones. As a result, a national cultural policy encapsulates the main features of the national political and cultural histories. This is the reason why cultural policy is a fascinating topic for an international comparison that brings together political, cultural and social aspects. But this sedimentation and 
multidimensional aspects also complicate a cross-national perspective. Three series of questions help to identify the principles of differentiation between the various cultural policy regimes and to account for their evolution. How is cultural policy defined as a specific policy domain, and what are the issues at stake in this definitional process? What are the main rationales for cultural policy? And finally, what is the relationship between the organizational structure of cultural policy and the cultural and political issues it raises? By addressing these questions, we will shed light on the process of making a specifically "cultural" policy and see how it is being increasingly challenged by ongoing political and cultural changes in Europe.

\section{Defining Cultural Policy}

\section{Historical Legacies}

The political uses of the arts as symbols of power are the most common features of the protohistory of modern cultural policies in Europe. Princes, lords and monarchs all over the continent have commissioned and accumulated works of art, decorated palaces, supported artists and funded music, theater and festivals in order to assert their grandeur. During the Renaissance, when the private fortune of the ruling king or queen was distinguished from the public possessions of the state, this personal and private patronage progressively turned into a state affair. Specific services were created to administrate the arts. Beyond the individual pleasures and fame of the monarch, the magnificence, prestige and moral authority of the state, in competition with the church, was from henceforth stake.

If they share this common legacy, cultural policy regimes differ according to the various national histories of nation building and of the making of the modern state. In countries which 
saw early unification of the nation and building of a powerful state, the arts and culture were directly related to these processes. France certainly is the most obvious example of this link. Linguistic unification was a means to exert power throughout the national territory, and also the condition for the early invention of a national literature, which, in return, contributed to the adhesion to a unified politico-cultural community. In that sense, the creation of the French Academy (Académie française) in 1635 was both a literary and linguistic contribution to the making of the French nation-state, and a political contribution to the formation of the national literary field. More generally, political and cultural centralization were joint processes. As a result, a unified state, a national culture, and the subsequent link between state and culture were historically made self-evident. On the contrary, the history of nation and state building in more recently unified countries leads to totally different consequences in terms of cultural policy regime. The history of the relationship between the arts and politics in Italy, for instance, has been the history of the competition between cities for several centuries (Castelnuovo, Ginzburg, 2009). The political and artistic polycentrism of the peninsula rooted in the Italian Renaissance has had long-lasting effects in terms of cultural policy. In other cases, such as Finland, the relationship between culture and politics was defined in the scope of a late and impeded nation building, in order to promote a nationally representative art after 1860 , and in order to create a sense of national community during the first decades of the twentieth century (Sokka \& Kangas, 2007).

The political uses of culture can also result in illegitimate legacies that have hindered the founding of cultural policy regimes in the contemporary era. This has occurred in countries in which authoritarian and fascist regimes have manipulated the arts and culture. The main example is Nazi Germany, during which arts censorship and political propaganda through culture was stronger than anywhere else in Western Europe, with a direct impact in terms of 
reluctance towards a state-driven cultural policy in West Germany after World War II. To a lesser extent, a negative cultural legacy has impeded the making of democratic cultural policies after authoritarian regimes in Italy, Spain and Portugal. Contemporary cultural policy regimes result from these various national histories, which have led to various notions of viewing culture and its political aspects, and provided various legacies in terms of institutions, types of funding and modes of organization.

\section{Specifying a Policy Domain}

The definition of a cultural policy does not, however, only consist in these historical legacies. Besides "implicit" cultural policies, namely the wide set of public decisions and programs which have cultural impacts even if they are not conceived and presented as pursuing cultural goals (Ahearne, 2009), explicit and specific cultural policies have been defined as such, in most European countries, from the 1960s onwards. National and local governments have created a new policy category (Dubois, 2012a), bringing together new functions, previous forms of public support for the arts, and closely related policy domains. However, the idea that culture is per se a legitimate field for public policy is still diversely appreciated from one context to another. If the term "cultural policy" itself is common in the French political discourse since the 1960s, it has rarely been used at the European Union level, for instance.

What cultural policy includes is also variable in time, and from one country to another. The core commonly includes historical heritage, support of professional artists, and traditional cultural institutions such as libraries, museums, theaters and concert halls. Quite a few other sectors or issues variably complement it, such as popular, regional or migrant cultures, language, sports, media, leisure, after school and social activities, cultural education, or the 
amateur arts. What cultural policy includes or excludes in a specific national and historic context is not only a matter of bureaucratic organization, it partly reflects the boundaries of the legitimate domain for public intervention in a given society. It also reflects the definition of culture which prevails and which is promoted by public authorities.

Cultural public policy participates in the classification process that separates art from non-art, or at least valuable from less valuable art (DiMaggio, 1987). As Heikkinen shows in the case of Northern Europe, the administrative categories used to classify art and artists vary from one country to another according to the interaction between the state and the artistic field specific to each national context (Heikkinen, 2005). The extent to which public authorities determine these classifications or simply follow those defined by the art market is a good indicator of a cultural policy regime, since it reveals the relative weight and symbolic authority of the state and of the market in cultural affairs. With strong national differences, European cultural states gained power in this respect from the 1960 s to the 1980 s, but the market has become dominant again in the following period.

Beyond classification in art, the definition of culture in cultural policy plays a more general symbolic role in society. The core of the cultural policy domain basically corresponds to the legitimate definition of culture, that is to say the culture of the elite (Bourdieu, 1984). The extension of this domain then consists in the inclusion of the culture of other social groups, which raises the issue of their symbolic status. We can think here of three main cases. In Western Europe, as opposed to the Eastern part of the continent, the culture of the working class has generally been initially excluded from the field of state cultural policy, but promoted by social movements and political organizations, such as the Communist party. Declining traditional aspects from working class cultures have later been taken into consideration, 
mainly in the perspective of preserving their heritage (Dubois, 2011a). Regional and local subcultures are a second example. They have long been promoted in federalist and highly decentralized countries, where they represent the cultural counterparts of political claims toward the national level. Their partial recognition participates in the highly debated symbolic redefinition of the nation in unitary nation states. The third and currently prominent example concerns the cultures of immigrants. The inclusion of these cultures in the field of public policy serves as a symbolic tool for the inclusion of immigrants in society. This, again, is highly debated in many countries, including Germany, where the multikulti orientation of soziokultur programs, initially promoted by activists at the local level, has been included in official national policies from the 1980s onwards. It is also debated in France, where the reticence emanating from the tradition of a unified Republican political and cultural model limits the development of such programs (Kiwan, 2007).

\section{An Increasingly Uncertain Domain}

Although the borders of cultural policies have not been strictly defined in the past, they are probably even less so today. The specification of culture as a policy domain currently faces three principal challenges. The first one is not entirely new, and concerns the redefinition of culture. As long as a restrictive and elite notion of culture prevails, the outlines of cultural policy remain quite easy to draw. They broadly correspond to the field of art and heritage, to which are added educational and social aspects. But the invention of new artistic genres or disciplines (such as video art or street art, for instance) and the questioning of the notion of art by postmodern artists resulted in the constant redefinition of the borders of art itself. In addition and sometimes in relation to these redefinitions, the narrow perimeter of culture as legitimate art and the elitist conception it entails has been contested at least since the end of 
the 1960s. The spreading of a more comprehensive and anthropological notion of culture and the claims for cultural recognition by minority groups have participated in making the definition of culture (and then of cultural policy) problematic from a social and political point of view. A second challenge results from the changes in the access to culture. As long as this access was mainly provided by institutions, such as theaters, or by media that could be directly regulated by public agencies, such as radio and television, the territory of cultural policy could correspond to the addition of these institutions and media. The advent of the Internet, which now plays a major role in the diffusion of cultural goods, and is far more difficult to regulate, leads to the fact that a substantial part of culture now is out of reach from traditional cultural policies. Last, new ways of considering the borders of the cultural field have challenged the definition of cultural policy. Since the 1990s, the idea of creative industries and of a creative economy has emerged in the Anglophone world and has experienced a great success in Europe, starting with the United Kingdom (Hughson \& Inglis, 2001). The notion of creative industries overlaps with the notion of cultural industries, although it is definitely a broader one. It adds design, advertising, fashion, software, computer games, etc., to the more traditional sectors of publishing, television, film or performing arts. The notion of creativity tends to replace the notion of arts and culture in policy discourses, at the EU level and to a lesser extent in national and local governments. This evolution tends to replace cultural policy as a specific domain with a policy promoting the new model of a creative economy, in which culture is included, but diluted. 


\section{Specifying Cultural Policy Rationales}

\section{The Original Trilogy: Heritage, Artistic Creation and Access}

Cultural policy regimes in Western Europe have been built on three principal shared policy rationales. The first one pertains to the preservation of artistic and historic heritage. This is basically acknowledged as a legitimate state function, even in non-interventionist liberal contexts. In most European countries, heritage is generally regarded as national heritage, which is closely related to the national history and identity. Heritage protection corresponds to the model of a regulatory state, which establishes legal rules in order to prevent the loss of what is defined as public goods. It is an example of the previously mentioned classificatory role of cultural policy. In addition to legal protection, costly heritage maintenance requires funding that private individuals or organizations generally cannot afford by themselves. This financial issue has justified public expenses for culture over the two last centuries. In countries such as Italy, for instance, private foundations have nevertheless traditionally played a key role in the preservation of heritage. This is now a general trend in European heritage policies which questions the oldest legitimate basis for the intervention of public authorities in cultural affairs.

A second basic rationale for contemporary public policy is support for artistic creation. Even though there are similarities and continuity between the two, this support differs from the ancient model of state patronage. The manipulation of the arts as symbols of political power is no longer the major aspect of commissioning and subsidizing artists. This support is primarily based on the idea according to which the market is not sufficient to promote artistic creation and innovation. In contemporary visual arts or in literature we could say that public support of 
creation is currently ancillary to the art or the publishing markets. But in contemporary art (i.e. experimental music) or to a lesser extent in theater, private demand and consumption could not suffice to fund creation. Cultural policy then aims to provide the conditions for this creation to exist. It can more ambitiously aim at preserving part of the field of artistic creation from the necessity of profitability, which in other words means enabling the implementation of the specific "rules of art" in lieu of letting the economy rule the art (Bourdieu, 1995). This ambitious rationale for cultural policy raises, however, the issue of the extent to which public bodies should make artistic choices and, by doing so, should promote certain aesthetic and moral values above others. In order to avoid the specter of "official art", democratic cultural policy regimes have created forms of delegation of artistic judgment, through experts, commissions and cultural organizations co-managed by officials and artists. This delegation of judgment is a major distinctive feature of these regimes.

The relationship between democracy and culture is also central to the third main rationale for contemporary European cultural policies, that is, equal access to culture (International Journal of Cultural Policy, 2012). The idea of the necessity for the people to access education, arts and culture so as to gain individual autonomy and to become able to exert citizenship dates back to the Age of Enlightenment. It was translated into a policy goal and has become a guiding principle for cultural policy in the postwar period. We could say that it was the cultural component of the making of European welfare states, which added cultural entitlements to social rights to achieve a more equal and inclusive society. The notions of cultural democratization and equal access to the arts were all the more successful insofar as they could easily bring politicians and cultural actors to a common ground. They were consequently central in the legitimization of modern public cultural policies differentiated 
from past forms of public support to the arts, with some exceptions such as Greece, where cultural policy focused on heritage and disregarded the democracy dimensions (Zorba, 2009).

These general notions, however, comprehend various if not contradictory orientations. The civic perspective of autonomous individuals able to participate in community life thanks to culture meets educational policies. The humanist and somewhat paternalistic perspective of pushing the lower classes toward greater participation in highbrow culture pertains to a paradoxical form of elitism grounded on the idea that only the upper educated echelon knows what is real culture, and what is good for the people. Conversely to this top-down approach, the claim for cultural democracy consists in the desacralization of elite culture and in the achievement of cultural diversity forms that envision democratization from a bottom-up perspective (Bonet \& Négrier, 2011; de Jong, 1998; Saukkonen \& Pyykkönen, 2008). The balance and combinations between these orientations varies in time and space. A legitimist and elitist approach to the dissemination of culture in society prevailed until the late 1960s. From then on, this model has been contested, but it has not been entirely replaced by an alternative model. Current cultural democratization policies and discourses actually articulate different strata that may be logically incompatible but are combined in practice. Generally speaking, the legitimist approach remains important, as it reflects the predominance of elite cultural institutions in European cultural policies, but is nuanced by programs that are conceived in a more participatory way, or more oriented toward the promotion of cultural diversity. 


\section{From the Diversification of Goals to the Non-Cultural Rationales of Cultural Policy}

This original trilogy sets the basis for policy objectives proper to cultural policy and that aim at specifically cultural purposes. This should not, though, be taken for granted. First, these core rationales have always been combined with other policy goals (Gray, 2009). The search for national prestige and influence at the international level is an example of the link between cultural policy and diplomacy. Among other things, most European governments have established a network of cultural centers abroad, such as the British Council or the Goethe Institut. The making and promotion of collective identity through culture lasts long after the early period of nation-building, as we have seen after German reunification in 1990, or in the renewal of political uses of history in Spain, France, or even at the EU level during the past two decades. In addition, public cultural policies have a wide range of specifically social policy goals, from urban regeneration to the supervision of idle youth in deprived neighborhoods, from the empowerment of disabled persons to the regulation of ethnic and cultural diversity and to the alleviation of social exclusion (Belfiore, 2002). Last but not least, culture is considered as a means to achieve economic goals. Beside cultural concerns, festivals, museums or historic buildings are envisioned and publicly funded qua assets in terms of touristic attractiveness. Cultural organizations and training in cultural professions are also supported because the culture is a dynamic sector in terms of employment.

Second, each of the three main objectives specific to cultural policies is challenged in various ways. The protection of heritage is nowadays less than ever a monopoly of the public sector. In addition, the narrow definition of heritage as the legacy of celebrated works of art and buildings from the past has progressively been replaced from the beginning of the 1980s by a much broader one, a potentially never-ending list, which includes industrial sites, folk 
traditions or local dialects. This broadening accounts for the changes in the relationship of Western societies to their past. It also transforms the role of heritage policies, which, more than ever, "invent" rather than only protect heritage. All of this questions the self-evidence of heritage preservation as a public policy function. In times of economic crisis, public support of artistic creation is questioned, especially when this creation hardly meets any demand from the audience. On the other hand, the role of public agencies is weakened by speculation in the art market and the increase in prices. Cultural democratization, that is, the prominent objective and legitimizing discourse in the development of contemporary cultural policies in Europe, has also lost an important part of its strength as a political and cultural guiding principle. The contestation of a unique and universal notion of culture, from counter-cultural movements in the late 1960 s to the current promotion of cultural diversity, has weakened the belief in the legitimist cultural model on which cultural policies have been founded. The mixed results, if not the failure of several decades of public cultural policies in the reduction of social inequalities in cultural participation, have also shaken the founding myth of cultural democratization. Moreover, the huge development of ways to access culture, television and subsequently the Internet, has increasingly competed with cultural policies, mainly focused on traditional institutions such as libraries or theaters.

Finally, the balance between strictly cultural objectives and non-cultural goals has moved toward the latter orientations. Conversely to the specialization and specification processes that started in the postwar period and resulted in asserting cultural policy goals for the sake of culture, public intervention in cultural matters is at present increasingly assigned non-cultural purposes, among which economic ones prevail. Public cultural expenses are gradually viewed in terms of investments from which economic impacts are expected. This is the case even in countries with a strong cultural policy and welfare-state tradition, such as France or Northern 
European countries (International Journal of Cultural Policy, 2008). The successful notion of creativity has become the keyword of current cultural policies. This makes the arts lose their specificity by linking them to entertainment and by viewing them as part of a fuzzy ensemble (the creative sector) defined on an economical rather than on a cultural or aesthetic basis. As a result, national cultural policies change from "intrinsic" to "instrumental" (Orr, 2008; Vestheim, 1994), jettisoning part of their cultural rationales in favor of economical ones, and contributing to a new form of "cultural capitalism" (McGuigan, 2004). This is ironic when we remember that contemporary European cultural policies have partly been conceived to protect arts and culture from the rules of the economic market. At the EU level, instead of developing proper cultural policies, the addition of "cultural dimensions" to economic and social policies

("mainstreaming") frames and defines the criteria for cultural projects according to the rationales of economic and social programs (Gordon, 2010). This illustrates the cultural and political implications of the organizational structure of cultural policy.

\section{Organizing Cultural Policy in Europe: Structures and}

\section{Governance}

\section{Social, Political and Institutional Settings}

Beyond its technical aspects, the organizational structure of cultural policy raises the question of who is legitimate to define collective cultural orientations. The general public is usually not part of the cultural policy making processes, although there have been some recent attempts to include satisfaction of the citizenry in the policy evaluation criteria. The organized interaction between public officials and professional representatives of artistic sectors is far more important, and there are examples of co-management, such as cinema in France, or in the 
Nordic countries. Public intellectuals can be influential, which is also an indicator of cultural policy as an issue in the public debate (Ahearne \& Bennett, 2007; Burns \& van der Will, 2006; Dubois, 2011b).

The organizational structure of cultural policy also raises the question of how the sensitive and highly symbolic matters of arts and culture should be governed. In liberal democratic regimes such as Western European states the mode of governance is required to exclude any possible resemblance to the authoritarian model of arts and culture controlled by the state apparatus. This is a strong political constraint for the institutions that elaborate, implement and embody national cultural policies. Two models are generally considered to account for Western European cultural policy (Hillman-Chartrand \& McCaughey, 1989). The "architect state" relies on centralized ministries. In this case, a specific department for culture within the national government concentrates a predominant part of the financial, political, informational and symbolic resources for cultural policy-making. Such a department asserts the role of the state in culture and is the main center for institutional and symbolic power in this domain. This type of interventionist state involvement characterizes France, while most governments adopt a less directly activist role. The latter represents the ideal type of the "patron state", dispensing funds through quasi-independent institutions. The Arts Councils in Great Britain exemplify a public body which operates at "arm's length", i.e. in relation with the national government but outside its departmental internal structure. This is supposed to protect from a possible excessive political leadership.

While this dual opposition helps to set the landscape of national cultural policy structures, it is, of course, not sufficient. The actual governance systems have never been as simple as that. They also have experienced important changes, such as the relative decline of the French 
ministry for culture, or the increasing control of the British government and its department for media, culture and sports over the Arts Councils. In these two countries as elsewhere in Europe, governments increasingly use tax policies to promote private patronage, which refers to the third type, a "facilitator state", of which the United States provides an example. There is neither a strong national ministry for culture, nor a strong arts council in Germany or in Italy, whereas there are both in the Nordic countries (International Journal of Cultural Policy, 2008).

Whatever the case, the previously mentioned political constraint in democratic regimes results in the fact that there is no institutional system in contemporary Western Europe in which there is a sole decision and bureaucratic monopoly on culture. As a policy area, culture is shared between infra-national, national and supra-national policy levels, with strong connections to the nonprofit private sector (Burns \& Van der Will, 2003; Stevenson, McKay \& Rowe, 2010). This multi-level complexity characterizes all European countries, including those usually regarded as having a high level of state centralism such as France, where the national government is responsible for less than $50 \%$ of the total of the public budget for culture, and where all the politico-administrative levels (municipalities, intercommunity structures, departments and regions) have jurisdiction over culture.

This is, however, far from avoiding jurisdiction conflicts and debates about which level is most legitimate and best suited to take care of cultural affairs (Dubois et al., 2012b). While such conflicts and debates occur in any kind of political and institutional system, they are of particular importance in the countries where infra-national and national governments compete for political legitimacy. This is clearly the case in Spain, where this competition is a factor in the apparent inconsistency of the multi-level governance of cultural policies, and where 
diversity results in the non-existence of a formal Spanish model of cultural policy (Bonet \& Négrier, 2010). Although Spain is an extreme case, all European countries experience to various extents comparable dynamics between center and periphery, and decentralization has generally been increasing for the three last decades.

\section{Funding Culture}

Cultural policies are often identified with public financial support for the arts and culture. This is obviously simplistic, since they use a wide range of policy tools, from market regulation to organizational reform, but underlines that funding is a key issue. To some extent, cultural policy regimes then consist in cultural funding modes. These regimes are difficult to compare. A rough approximation shows that the public expenditures for culture range from around $0.5 \%$ to $2.5 \%$ of the total of public budgets of Western European countries in 2010-11 (Council of Europe \& ERICarts, 2012). This does not indicate much since all of them mix various financial aspects, which are almost impossible to assess in a single figure (Alexander, 2008). In addition to the most direct forms of funding, that is to say public budgets for state-controlled institutions, such as public libraries, and subsidies granted to individual artists or nonprofit arts organizations, there are many other indirect forms, such as social security benefits paid to artists, support to private companies in the cultural industries, or tax incentives for the patronage of the arts. This strongly varies from one country to another. A general tendency, however, is the predominance of support to arts institutions. More precisely, European cultural policies have to a large extent consisted in creating new arts institutions in order to extend the supply of culture. This plays a direct role in the current financial crisis of cultural policy whose budget is widely absorbed by the costs to run these 
institutions. This crisis is all the more acute as that stagnation if not retrenchment come after decades of increase in the cultural public budgets.

This has changed the debate on who is to pay for culture. In the period of development of national cultural policies, which coincided with a general growth of public budgets, national states and local authorities have increased their cultural expenditures, sometimes considerably. Because of financial difficulties but also because of neoliberal policies, governments have looked for new financial sources, including the national lottery in the United Kingdom in the mid-1990s. The general trend toward decentralization, which had previously accompanied the global development of cultural policies, is now often related to the withdrawal of the national governments. As a result, cultural policies increasingly appeal to the private sector. This brings European cultural policy regimes in some ways closer to the U.S. model in which cultural organizations have to raise money. Tax incentives for the private patronage of the arts are now a common feature of public policies for culture in Europe, where they sometimes are more favorable than they are in the United States. This does not amount to the end of European cultural policy regimes, but is part of the redefinition process they are experiencing. 


\section{References}

Ahearne J. \& Bennett O. (eds.), 2007. Intellectuals and Cultural Policy. London: Routledge.

Ahearne, J., 2009. Cultural Policy Explicit and Implicit: A Distinction and Some Uses. International Journal of Cultural Policy 15(2), 141-53.

Alexander, V., 2008. Cultural Organizations and the State: Art and State Support in Contemporary Britain. Sociology Compass, 2(5), 1416-30.

Belfiore, E., 2002. Art as a Means of Alleviating Social Exclusion: Does it Really Work? A Critique of Instrumental Cultural Policies and Social Impact Studies in the UK. International Journal of Cultural Policy, 8(1), 91-106.

Bonet, L., \& Négrier, E., 2010. Cultural Policy in Spain: Processes and Dialectics. Cultural Trends, 19(1-2), 41-52.

Bonet, L., \& Négrier, E., 2011. The End(s) of National Cultures? Cultural Policy in the Face of Diversity. International Journal of Cultural Policy, 17(5), 574-89.

Bourdieu, P., 1984. Distinction. Cambridge, Harvard University Press.

Bourdieu, P., 1995. The Rules of Art. Stanford, Stanford University Press. 
Burns, R., \& Van der Will, W., 2003. German Cultural Policy: An Overview. International Journal of Cultural Policy, 9(2), 133-152.

Burns, R., \& van der Will, W., 2006. Intellectuals as Cultural Agenda-Setters in the Federal Republic? International Journal of Cultural Policy, 12(3), 291-322.

Castelnuovo, E., Ginzburg, C., 2009. Symbolic Domination and Artistic Geography in Italian Art History. Art In Translation 1(1), 5-48.

Council of Europe \& ERICarts, 2012. Compendium of Cultural Policies and Trends in Europe. www.culturalpolicies.net (accessed 02.11.13.)

de Jong, J., 1998. Cultural Diversity and Cultural Policy in The Netherlands. International Journal of Cultural Policy, 4(2), 357-87.

DiMaggio, P., 1987. Classification in Art. American Sociological Review, 52, 440-55.

Dubois, V., 2011a. Lowbrow Culture and French Cultural Policy. The Socio-political Logics of a Changing and Paradoxical Relationship. International Journal of Cultural Policy 17(4), 394-404.

Dubois, V., 2011b. Cultural Capital Theory vs. Cultural Policy Beliefs: How Pierre Bourdieu Could Have Become a Cultural Policy Advisor and Why He Did Not. Poetics, 39(6), 491-506.

Dubois, V., 2012a. La Politique Culturelle. Genèse d'une Catégorie d'Intervention Publique, second ed. Belin, Paris. 
Dubois, V., (with Bastien, C., Freyermuth, A., \& Matz, K.), 2012b. Le Politique, l'Artiste et le Gestionnaire. (Re)configurations Locales et (Dé)politisation de la Culture, Bellecombe-enBauges: Le Croquant.

Gordon, C., 2010. Great Expectations. The European Union and Cultural Policy: Fact or Fiction? International Journal of Cultural Policy, 16(2), 101-20.

Gray, C., 2009. Managing Cultural Policy: Pitfalls and Prospects. Public Administration, 87(3), 574-85.

Heikkinen, M., 2005. Administrative Definitions of Artists in the Nordic Model of State Support for Artists. International Journal of Cultural Policy, 11(3), 325-40.

Hillman-Chartrand, H., \& McCaughey, C., 1989. The Arm's Length Principle and the Arts: An International Perspective. In Cummings, M.C., \& Schuster, M., (eds.), Who's to Pay for the Arts? The International Search for Models of Support. NewYork, American Council for the Arts, 43-80.

Hughson, J., \& Inglis, D., 2001. 'Creative Industries' and the Arts in Britain: Towards a Third Way in Cultural Policy? International Journal of Cultural Policy, 7(3), 457-78.

International Journal of Cultural Policy, 2008. "Nordic cultural policy”, 14(1).

International Journal of Cultural Policy, 2012. "Cultural Policy and Democracy”, 18(5). 
Kiwan, N., 2007. When the Cultural and the Social Meet: A Critical Perspective on SociallyEmbedded Cultural Policy in France. International Journal of Cultural Policy, 13(2), 153-67.

McGuigan, J., 2004. Rethinking Cultural Policy. Open University Press, Maidenhead.

Orr, J., 2008. Instrumental or Intrinsic? Cultural Policy in Scotland Since Devolution. Cultural Trends, 17(4), 309-16.

Saukkonen, P., \& Pyykkönen, M., 2008. Cultural Policy and Cultural Diversity in Finland. International Journal of Cultural Policy, 14(1), 49-63.

Sokka, S., \& Kangas, S., 2007. Intellectuals, Nationalism, and the Arts. International Journal of Cultural Policy, 13(2), 185-202.

Stevenson D., McKay, K., \& Rowe, D., 2010. Tracing British Cultural Policy Domains: Contexts, Collaborations and Constituencies, International Journal of Cultural Policy, 16(2), $159-172$.

Vestheim, G., 1994. Instrumental Cultural Policy in Scandinavian Countries. European Journal of Cultural Policy, 1(1), 57-71.

Zorba, M., 2009. Conceptualizing Greek Cultural Policy: The Non-democratization of Public Culture. International Journal of Cultural Policy, 15(3), 245-59. 